\title{
Adenosinergic-Dopaminergic Signaling in Mood Disorders: A Mini-Review
}

\author{
Maria Carolina Bittencourt Gonçalves, PhD, Talita Glaser, PhD, \\ Sophia La Banca de Oliveira, PhD, and Henning Ulrich, PhD
}

\begin{abstract}
Mood disorders are one of the biggest health problems, affecting the patients' emotional state, who experience depression or extreme euphoria or both of these. This review will focus on the participation of adenosinergic signaling in major depressive disorder and bipolar disorder (BPD) as well as in schizophrenia and schizoaffective disorder. Adenosine receptor activation may induce antidepressive actions in animal models, either by enhancing the $A_{1}$ receptor or decreasing the $A_{2 A}$ receptor activity. On the contrary, $A_{1}$ receptor activation can lead to manic-like behaviors in BPD models. Strong evidence points to adenosine modulation of the dopaminergic system, which has an important role in the pathophysiology of mood disorders. Most notable are the adenosine-dopamine receptor heteromers. Two of them, $A_{2 A}-D_{2}$ and $A_{1}-D_{1}$ receptor dimers, are well characterized, but $A_{2 A}-D_{3}, A_{2 A}-D_{4}$, and $A_{2 A}-D_{2}-D_{3}$ receptors heteromers have also been suggested. $\mathrm{A}_{2 \mathrm{~A}}-\mathrm{D}_{2}$ heteromers are highly expressed in corticostriatal pathways, which, in turn, are linked to the pathophysiology of mood disorders. Thus, further research on the role of adenosine-dopamine receptor heteromers in mood control may lead to a better understanding of mood disorders' pathophysiology and novel therapeutic tools.
\end{abstract}

Keywords: major depressive disorder, bipolar disorder, schizophrenia, receptor heteromer, glutamate, GABA

\section{Introduction}

$\mathbf{E}$ XTREME HAPPINESS, SADNESS, or both for long periods characterize mood disorders, which are mental health problems affecting the individual's emotional state. ${ }^{1}$ These disturbances cause big onus to society as they affect life quality and life span, ${ }^{1}$ being the leading cause of disability worldwide. ${ }^{2}$ Also considered affective disorders, ${ }^{3}$ mood disorders are classified by the World Health Organization (WHO) according to types of mood episodes, such as depressive, manic, mixed, or hypomanic episodes. ${ }^{4}$ Bipolar disorders (BPDs) and major depressive disorders (MDDs) are the most prevalent ones in the category. ${ }^{5}$ However, other disorders that fit in the mood spectrum, such as dysthymic disorder and cyclothymic disorder, are also part of the class. ${ }^{6}$ Prolonged phases of depressive episodes, the lower side of mood spectrum, characterize MDD, while BPD differs by alternating between depressive episodes and manic or hypo- manic episodes, of elevated mood. ${ }^{7,8}$ On the contrary, schizoaffective disorder (SCA) is a chronic mental health condition with a debatable classification that involves symptoms of both MDD or BPD and schizophrenia (SCZ). ${ }^{9}$ We consider SCA as a mood disorder, given that around 50\% of first hospitalizations reporting psychosis will be later diagnosed as SCA, and at least $25 \%$ of them were previously misdiagnosed as SCZ. ${ }^{10} \mathrm{SCZ}$ will be also discussed, as it shares many pathophysiological features with SCA, which lack specific data on adenosinergic signaling. Since mood alterations might be influenced by external factors, the prevalence of mood disorders is widely different among cultures. Mean percentages of $5 \%$ and $1.2 \%$ were determined throughout cultures as MDD and BPD prevalence, respectively. ${ }^{1,11}$ Because of the overlapping symptoms among SCZ, MDD, and BPD, the prevalence of SCA is unknown, even though some studies suggest that it might be between $0.2 \%$ and $1.1 \%{ }^{12}$

Departamento de Bioquímica, Instituto de Química, Universidade de São Paulo, São Paulo, São Paulo, Brazil. 
The causes of mood disorders are still unclear although diverse research in the field points to genetic predisposition, neurotransmitters imbalance, abnormal neurocircuitry, circadian system disturbances, impaired neuroplasticity, oxidative and neuroinflammatory processes, and substance abuse as promoters of mood dysfunctions. ${ }^{13-17}$

\section{Adenosinergic System and Mood}

The first observations of adenosine physiological properties were in 1929, but only in 2001, the receptors mediating adenosine signals were consensually classified based on their characterization. ${ }^{18}$ There are four adenosine receptor subtypes $A_{1}, A_{2 A}, A_{2 B}$, and $A_{3}$, differing by the type of $G$ protein coupling. $A_{1}$ receptors are usually coupled to $G_{i / o}$, whereas $A_{2 A}$ receptors act through $G_{s} \cdot A_{2 B}$ receptors activate phospholipase $\mathrm{C}$ via $\mathrm{G}_{\mathrm{q}}$ or $\mathrm{G}_{\mathrm{s}}$ stimulation. $\mathrm{A}_{3}$ receptors act mainly through $\mathrm{G}_{\mathrm{i}}$ and $\mathrm{G}_{\mathrm{q}}{ }^{19}$

Adenosine concentration in the brain increases along the day and controls together with melatonin the sleepwake cycle. ${ }^{20}$ Nevertheless, changes in the levels of adenosine in different moments and regions of the brain can be harmful and involved in neuroinflammation. ${ }^{21}$ The response to different levels of adenosine depends on the expression profiles of adenosine receptor subtypes and their respective binding affinities. For instance, $\mathrm{A}_{2 \mathrm{~A}}$ receptors have higher affinity to adenosine than $\mathrm{A}_{2 \mathrm{~B}}$ receptors. ${ }^{22}$

The role of the adenosinergic system in psychiatric diseases has drawn recent attention of scientists. ${ }^{23}$ Experimental evidence pointing to $\mathrm{A}_{1}$ receptor in MDD date back to 2013 by Hines et al. ${ }^{24}$ when they observed that the activation of the $A_{1}$ receptor led to sustained antidepressant behavior. Corroborating these data, Serchov, in 2012 and $2015,{ }^{25,26}$ induced overexpression of the $A_{1}$ receptor in forebrain neurons, eliciting antidepressant behavior, while $\mathrm{A}_{1}$ knockout mice presented depressivelike behavior. ${ }^{27}$

The $A_{2 A}$ receptor has also been described in MDD, mainly by its participation in inhibiting the $A_{1}$ receptor activity. ${ }^{28,29}$ In agreement, extensive work by other groups showed that antagonism of $\mathrm{A}_{2 \mathrm{~A}}$ receptor activity with caffeine or other pharmacological tools has an antidepressant effect, ${ }^{30-36}$ as reviewed by López-Cruz et al. ${ }^{37}$ Furthermore, different animal models of MDD presented augmented expression levels of the $\mathrm{A}_{2 \mathrm{~A}}$ receptor in the forebrain and striatum. ${ }^{38-41}$

Although mechanisms underlying $\mathrm{A}_{1}$ and $\mathrm{A}_{2 \mathrm{~A}}$ adenosine signaling in MDD have been extensively reviewed, their participation in other mood disorders is still under investigation. ${ }^{23,42,43}$ In a meta-analysis performed by Hirota and Kishi, adenosinergic modulators in clinical trials showed efficacy as adjuvant treatment for both BPD and SCZ, especially manic episodes and positive symptoms, respectively. ${ }^{44}$ The hypothesis of adenosinergic participation in SCZ is based mostly on alterations of
$\mathrm{A}_{2 \mathrm{~A}}$ receptor expression and activity and its modulatory effect on dopaminergic and glutamatergic systems, as reviewed by Boison et al. ${ }^{45}$ As further support for this hypothesis, postmortem brains of SCZ patients showed an increased density of striatal $\mathrm{A}_{2 \mathrm{~A}}$ receptor, ${ }^{46}$ although it is not clear whether this outcome is a secondary effect of antipsychotic treatments. ${ }^{47}$ When it comes to the $\mathrm{A}_{1}$ receptor, Brunstein et al. proposed that the efficacy of dipyridamole adjunctive treatment for SCZ is most likely to occur via adenosine $\mathrm{A}_{1}$ receptor. $^{48}$

The hypothesis of adenosinergic role in BPD relates to the excretion of uric acid, the final metabolite of adenosine degradation, in manic patients. ${ }^{41,49,50}$ In fact, adenosine and uric acid have been lately considered as biomarker candidates for manic and depressive episodes in BPD patients. ${ }^{51}$ Moreover, application of the xanthine oxidase inhibitor allopurinol increases adenosine levels and has positive effects in acute mania patients when used in combination with the mood stabilizers lithi$u^{52,53}$ or valproate. ${ }^{54}$ Peripheral adenosine levels are also reduced in euthymic BPD patients and this event was negatively correlated to depressive scores, indicating that depressive symptoms and impaired functioning might be associated to low levels of adenosine. ${ }^{55}$

Concerning adenosine receptors, $\mathrm{A}_{1}$ receptor activation may be antidepressant, while it may trigger symptoms of mania or hypomania in BPD patients. ${ }^{56}$ Following this line, the treatment of acute and dysphoric mania with carbamazepine, an anticonvulsant and moodstabilizing drug, is based on $\mathrm{A}_{1}$ receptor antagonism. ${ }^{57}$ $\mathrm{A}_{2 \mathrm{~A}}$ receptor expression levels were otherwise found upregulated in platelets of bipolar patients after administration of typical, but not atypical, antipsychotics. ${ }^{58} \mathrm{~A}_{2 \mathrm{~A}}$ receptors might be involved in impulsive and depressive features associated to suicidal behavior ${ }^{59}$ through downregulation of the adenosine $A_{1}$ receptor expression and upregulation of the glutamate N-methyl-D-aspartate (NMDA) receptor expression. ${ }^{60}$

\section{Dopaminergic System and Mood}

Despite its classical association to motor function control, dopamine is an important neurotransmitter also involved in behavior and cognition. Dopamine receptors were first described in 1972 when it was proposed that dopamine stimulates adenylate cyclase activity. ${ }^{61,62}$ Later, it was shown that dopaminergic signaling is mediated by two different families of $\mathrm{G}$ protein-coupled receptors. $D_{1}$-like receptors are positively coupled to adenylate cyclase and include $\mathrm{D}_{1}$ and $\mathrm{D}_{5}$ dopamine receptors. They stimulate the production of cyclic adenosine monophosphate (cAMP) through $\mathrm{G}_{\mathrm{s} / \mathrm{olf}}$ coupling and are mostly associated to the regulation of the reward system, locomotor activity, memory, and learning. $\mathrm{D}_{2^{-}}$ like receptors are otherwise independent of adenylate cyclase activation and include $\mathrm{D}_{2}, \mathrm{D}_{3}$, and $\mathrm{D}_{4}$ dopamine 
receptors. ${ }^{63}$ They couple to $\mathrm{G}_{\mathrm{i} / \mathrm{o}}$ and inhibit both adenylate cyclase activity and cAMP production, also being the main target of neuroleptic and antipsychotic drugs. ${ }^{64,65}$ An extend review on dopamine receptors was published by Beaulieu et al. ${ }^{66}$

The efficacy of drugs that act on the dopaminergic system to control mood and behavior both in human patients and in animal models of these diseases does not allow any doubts regarding the importance of dopaminergic signaling in mood disorders. An example is the antipsychotic drug cariprazine, which is a partial agonist of dopamine $\mathrm{D}_{2}$ and $\mathrm{D}_{3}$ receptors and the serotonin 5-HT $\mathrm{T}_{1 \mathrm{~A}}$ receptor, with a higher affinity for the $\mathrm{D}_{3}$ receptor compared to the further cited ones. Clinical trials have shown encouraging results for the treatment of MDD, BPD, and SCZ with cariprazine. ${ }^{67-69}$ The antianhedonic effect of this drug, which can be linked to its antidepressant effect in humans, is not present in $\mathrm{D}_{3}$ receptor knockout mice, corroborating that this receptor is at least partially involved in mood responses. ${ }^{69}$

Studies in animals indicate that the $\mathrm{D}_{1}$ receptor may be involved in depression. Levo-stepholidine had an antidepressant-like effect in Sprague-Dawley rats acting as a $D_{1}$ receptor agonist. ${ }^{70}$ Its mechanism depended on the PKA/mTOR downstream signaling pathway, resulting in the strengthening of synapses in the medial prefrontal cortex. ${ }^{70}$ Furthermore, overexpression of $\mathrm{D}_{1}$ receptor in the rat prefrontal cortex increased hedonic-like behaviors while inhibiting depressive-like behaviors. ${ }^{71}$ Reversion of overexpression abolished these effects, leading to depressive-like symptoms associated with BPD and suggesting a possible role of cycling $\mathrm{D}_{1}$ receptor expression in the pathophysiology of the disease. ${ }^{71}$

When it comes to animal mimicking of mood symptoms, the expression or activity modulation of dopaminergic system has been an important tool for the understanding of behavior, pathophysiology, and pharmacological responses. Notably, hyperdopaminergia has been used as a model of manic-like behavior through the selective inhibition of dopamine transporter (DAT) by GBR12909 administration ${ }^{72}$ or through the still unclear DAT/vesicular monoamine transporter mechanism underlying amphetamine administration in rodents. ${ }^{73}$ A comparative study in knockout mice showed that DAT blockade is more likely to result in antidepressant effects when compared to norepinephrine or serotonin transporter blockade. ${ }^{74}$

Another line of evidence for the participation of the dopaminergic system in mood disorders comes from receptor expression studies. Increases in $\mathrm{D}_{1}$ receptor mRNA transcription levels in the CA2 region of the hippocampus ${ }^{75}$ and dorsolateral prefrontal cortex ${ }^{76}$ and $\mathrm{D}_{2}$ receptors in the prefrontal cortex were observed in BPD patients. ${ }^{77}$ Differential splicing of the $\mathrm{D}_{2}$ receptor gene in the dorsolateral cortex changed with lower expression of the shorter and higher expression of the longer variant. ${ }^{76}$ In samples of peripheral lymphocytes, $\mathrm{D}_{3}$ receptor gene expression declined, which increased slowly following 3 weeks of treatment with antipsychotic drugs. ${ }^{78}$ In patients with MDD, gene expression of $\mathrm{D}_{4}$ receptors was significantly enhanced in the basal nuclei of the amygdala, whereas $\mathrm{D}_{1}$ and $\mathrm{D}_{2}$ receptor expression levels were not altered. ${ }^{79}$

Many studies investigating the role of dopamine in MDD used binding techniques to evaluate possible alterations in its signaling patterns in the brain. While one of them showed no significant alterations, ${ }^{80}$ many others found significant changes in the binding of $\mathrm{D}_{2}$ and $\mathrm{D}_{3}$ receptors in the temporal cortex, ${ }^{81}$ amygdala, ${ }^{82}$ and in different subsections of the striatum. ${ }^{83-85}$ The use of classical serotonin reuptake inhibitor antidepressants can also reduce the binding of $\mathrm{D}_{2}$ and $\mathrm{D}_{3}$ as suggested by Montgomery et al. ${ }^{86}$ These alterations may undermine the transference of information between different regions of the brain, as the increase of $\mathrm{D}_{2}$ and $\mathrm{D}_{3}$ receptorbinding sites in the striatum decreased connectivity in the corticostriatal-pallido-thalamic circuit. $^{87}$

In vivo binding to striatal $\mathrm{D}_{1}$ receptors in $\mathrm{MDD}$ patients is also affected in a strongly lateralized pattern, with left to right binding ratio being correlated inversely with illness duration. ${ }^{88}$ In postmortem brain, binding to DAT in the amygdala was reduced, while $D_{2}$ and $D_{3}$ receptor binding was increased, indicating that a reduced mesolimbic activity is also associated with MDD as previously hypothesized for rats. ${ }^{82}$

Another important line of evidence is the relationship between different genotypes and the susceptibility to mood disorders and the age of onset. A meta-analysis has shown that the G/G genotype on the rs 4532 locus of the DRD1 gene was associated with an increased risk for BPD. ${ }^{89}$ The same genotype has also been linked to an age of disease onset later than 18 years old. ${ }^{90}$ A few studies reported no genetic association of $\mathrm{D}_{2}$ receptors to $\mathrm{MDD}$, BPD, or SCA. ${ }^{91,92}$ Other works, however, found an association between the A1 allele of the polymorphism Taq1A on the DRD2 gene $^{93,94}$ and the allele 5 and genotype 5-5 of the intron 2 DRD2 microsatellite and the susceptibility to type II BPD. ${ }^{95}$ The GG genotype of the Taq1A polymorphism has also been linked to the early onset of BPD. ${ }^{96}$

Polymorphisms in the DRD2 gene are also connected to MDD. The A1 allele of the Taq1A polymorphism is associated with a lower binding of dopamine in the middle caudate and the ventral striatum, which in turn is associated with the susceptibility to depression. ${ }^{97}$ Another polymorphism, at the locus rs4460839 of the same gene, may play a role not only in the susceptibility to depression, but also in the onset-time of antidepressant response. ${ }^{98}$ Polymorphisms in the DRD3 and DRD4 genes have been also linked to BPD. The Ser ${ }^{9}$ Gly polymorphism of the DRD3 gene was associated with the development of type I, but not type II BPD. ${ }^{99,100}$ Two different polymorphisms in the DRD4 gene have been associated with BPD: the rs3758653, which has been linked to the development of type I BPD, ${ }^{101}$ and the 
DRD4-7R, which is associated with an early onset of BPD despite gender, and late-onset of SCZ in females. ${ }^{102}$

\section{Adenosinergic-Dopaminergic Interactions: Receptor Heteromers and Implications in Classical Mood Control Pathways}

The influence of caffeine and other adenosine modulators on dopamine receptor sensitivity and responsiveness has been proposed since the early 70 's. ${ }^{103}$ However, only in 1991, it was shown that the direct stimulation of the $A_{2 A}$ receptor reduces the affinity of $D_{2}$ receptor agonistbinding sites in striatal neurons. This suggests strong interactions between those receptors and may explain why adenosine receptor antagonists, such as caffeine, increases locomotor activity, while adenosine receptor agonists have an antipsychotic-like effect. ${ }^{104}$ Ever since, numerous works have explored pre- and postsynaptic direct interactions between the two systems, reinforcing an antagonistic association of adenosine and dopamine stimulation.

As the concept of receptor heteromers became better understood and accepted, scientists have driven strong attention to characterize receptor heteromers' functions in health and disease. ${ }^{105}$ Here, we assume the definition of receptor heteromer proposed by Ferré et al. as a "macromolecular complex composed of at least two (functional) receptor units with biochemical properties that are demonstrably different from those of its individual components"; it is also expected that heteromers have a direct physical interaction. ${ }^{106}$ The main adenosine-dopamine functionally relevant heteromers characterized up to now are $\mathrm{A}_{2 \mathrm{~A}}-\mathrm{D}_{2}$ and $\mathrm{A}_{1}-\mathrm{D}_{1}$ complexes, although there is also evidence of $\mathrm{A}_{2 \mathrm{~A}}-\mathrm{D}_{3}$ and $\mathrm{A}_{2 \mathrm{~A}}-\mathrm{D}_{4}{ }^{107,108}$ and more recently $\mathrm{A}_{2 \mathrm{~A}}-\mathrm{D}_{2}-\mathrm{D}_{3}$ receptor heteromers. ${ }^{107,108}$

Anatomically, $\mathrm{A}_{2 \mathrm{~A}}$ receptors are largely found in the basal ganglia, more specifically in striatopallidal GABAergic neurons from the dorsal striatum, ${ }^{109-111}$ where they coexist with $\mathrm{D}_{2}$ receptors. ${ }^{112}$ In fact, the striatum has emerged in the past years as a brain region encompassing mood control circuitry. Hyperactivation of the corticostriatal pathway has been associated with BPD, while its hypoactivation might be involved in MDD. ${ }^{113}$ While glutamate and GABA are well-known corticostriatal neurotransmission mediators of information processing, $\mathrm{A}_{2 \mathrm{~A}}-\mathrm{D}_{2}$ heteromers in this circuitry might also interplay to control neuropsychiatric behaviors, with an emerging role for adenylate cyclase 5 and antipsychotic effects of $\mathrm{A}_{2 \mathrm{~A}}$ receptor agonism/ $/ \mathrm{D}_{2}$ receptor antagonism. ${ }^{14-116}$

Despite the scenario reinforces the idea of the $A_{2 A}-D_{2}$ receptors heteromer playing an essential role in SCZ pathophysiology, ${ }^{117,118}$ data supporting the role of $A_{2 A}-D_{2}$ in BPD are still scarce and in need of further research. Only a few data identifying $A_{2 A}-D_{2}$ heteromers and increased levels of $\mathrm{A}_{2 \mathrm{~A}}$ in platelets of BPD patients under typical antipsychotic treatment have proposed such hy- pothesis. ${ }^{58} \mathrm{~A}_{2 \mathrm{~A}}-\mathrm{D}_{2}$ heteromeric receptor participation in MDD pathophysiology also needs further studies. Nevertheless, strong evidence for such correlation exists, since the administration of haloperidol, a classical antipsychotic with $\mathrm{D}_{2}$ antagonism mechanism, successfully prevented the antidepressant-like effect of the selective $\mathrm{A}_{2 \mathrm{~A}}$ antagonist SCH 58261 in the forced swim test. ${ }^{31}$ In view of that, adenosine-dopamine interactions in the prefrontal cortex are a promising target for antidepressants.

$\mathrm{A}_{2 \mathrm{~A}}$ receptors are also abundant in glutamatergic terminals in the hippocampus, ${ }^{42}$ a region where the number of dopaminergic active neurons is enhanced by NMDAglutamate receptor activation and GABAergic inhibition, ${ }^{119,120}$ and this effect has been associated to MDD and SCZ. ${ }^{121,122}$ Abnormalities in both glutamatergic and GABAergic signaling have been observed in mood disorders. ${ }^{123}$ Elevated glutamate signaling has been strongly associated with BPD and SCZ, in contrast to reduced signaling in MDD; however, magnitudes of these alterations differ among the brain regions. ${ }^{124,125}$

Although alterations in GABAergic signaling have been observed in BPD patients, GABA modulators' therapeutic efficacy is controversially discussed. ${ }^{126}$ GABA levels and signaling are significantly decreased in plasma, cerebrospinal fluid, and brain samples from MDD patients, and some of these observations have also remained after disease remission, suggesting that GABA is involved in the disease pathophysiology, but is not a good biomarker. ${ }^{126}$ Nevertheless, drugs that enhance GABAergic neurotransmission are promising for treating mood alterations, but are not notably specific only for mood disorders. ${ }^{127}$ These data suggest that a deeper investigation in the regulatory mechanisms of glutamate/GABA balance is of interest, ${ }^{123,126}$ and adenosine-dopamine signaling might play an important role, ${ }^{125}$ especially considering the glutamate-GABA modulatory effect of both $\mathrm{A}_{2 \mathrm{~A}}$ and $\mathrm{D}_{2}$ receptors individually. ${ }^{128,129}$

The aforementioned findings regarding the $\mathrm{A}_{2 \mathrm{~A}}$ receptor and the $\mathrm{D}_{2}$ receptor in GABAergic neurons were the first evidence of a possible role of adenosine-dopamine receptors integrated functional control of neuropsychiatric symptoms; however, there is emerging evidence of other heteromers' participation. As the role of the $\mathrm{D}_{3}$ receptor in mood disorders is being investigated, ${ }^{69,78,130}$ the antagonistic modulation of $\mathrm{A}_{2 \mathrm{~A}}-\mathrm{D}_{3}$ heteromer is proposed as a possible antischizophrenic approach. ${ }^{131}$ Further research regarding its effect, as well as $\mathrm{A}_{2 \mathrm{~A}}-\mathrm{D}_{2}-\mathrm{D}_{3}$ receptors in MDD and BPD could bring new insights for the treatment of mood symptoms. Despite the strong evidence of $\mathrm{A}_{1}-\mathrm{D}_{1}$ heteromer presence in basal ganglia circuits, ${ }^{132}$ no relevant inputs of its role in mood responses have been proposed yet.

\section{Perspectives}

Neuropsychiatric diseases, especially mood disorders, are known by their multifaceted and complex neurobiology. 
Although many different hypotheses have emerged to explain the pathophysiology of MDD, BPD, and SCZ/SCA, the whole picture associated with mood control remains unclear. Mood, cognition, and behavior have been traditionally linked to dopaminergic and glutamatergic pathways, but strong evidence during the past decades has supported a possible role of adenosine in these processes, including the idea of an integrated signaling mechanism within adenosinergic and dopaminergic systems in a more specific way.

In this study, we revisited these two systems and discussed how they are individually involved in mood disorders' biology, symptomatology, and response to treatments, reinforcing a possible role of the direct interaction of adenosine and dopamine receptors through heteromer formation, as summarized in Figure 1. The role of these interactions in classical glutamatergic and GABAergic neurotransmission mechanisms associated with mood control should also be taken into consideration for further investigations. Despite the most common evidence of $\mathrm{A}_{2 \mathrm{~A}}-\mathrm{D}_{2}$ receptor interactions in the central nervous system in mood control circuitries, $\mathrm{A}_{2 \mathrm{~A}}-\mathrm{D}_{3}, \mathrm{~A}_{2 \mathrm{~A}}-\mathrm{D}_{4}$, and possibly $\mathrm{A}_{2 \mathrm{~A}}-\mathrm{D}_{2}-\mathrm{D}_{3}$ receptors might be also of interest regarding mood symptoms, as well as their interaction with glutamate receptors, such as the mGlu5 subtype. ${ }^{133,134}$

The data here reviewed greatly suggest that identification, functional characterization, and specific modulation of adenosine-dopamine heteromers in specific brain regions and classical dopaminergic pathways, such as the mesocortical and mesolimbic ones, might be of interest for new therapeutic tools for mood disorders. Such understanding might help to better elucidate the different mechanisms underlying MDD, BPD, and SCA/SZC pathophysiology, promoting the development of new specific therapeutic strategies for mood disorders.
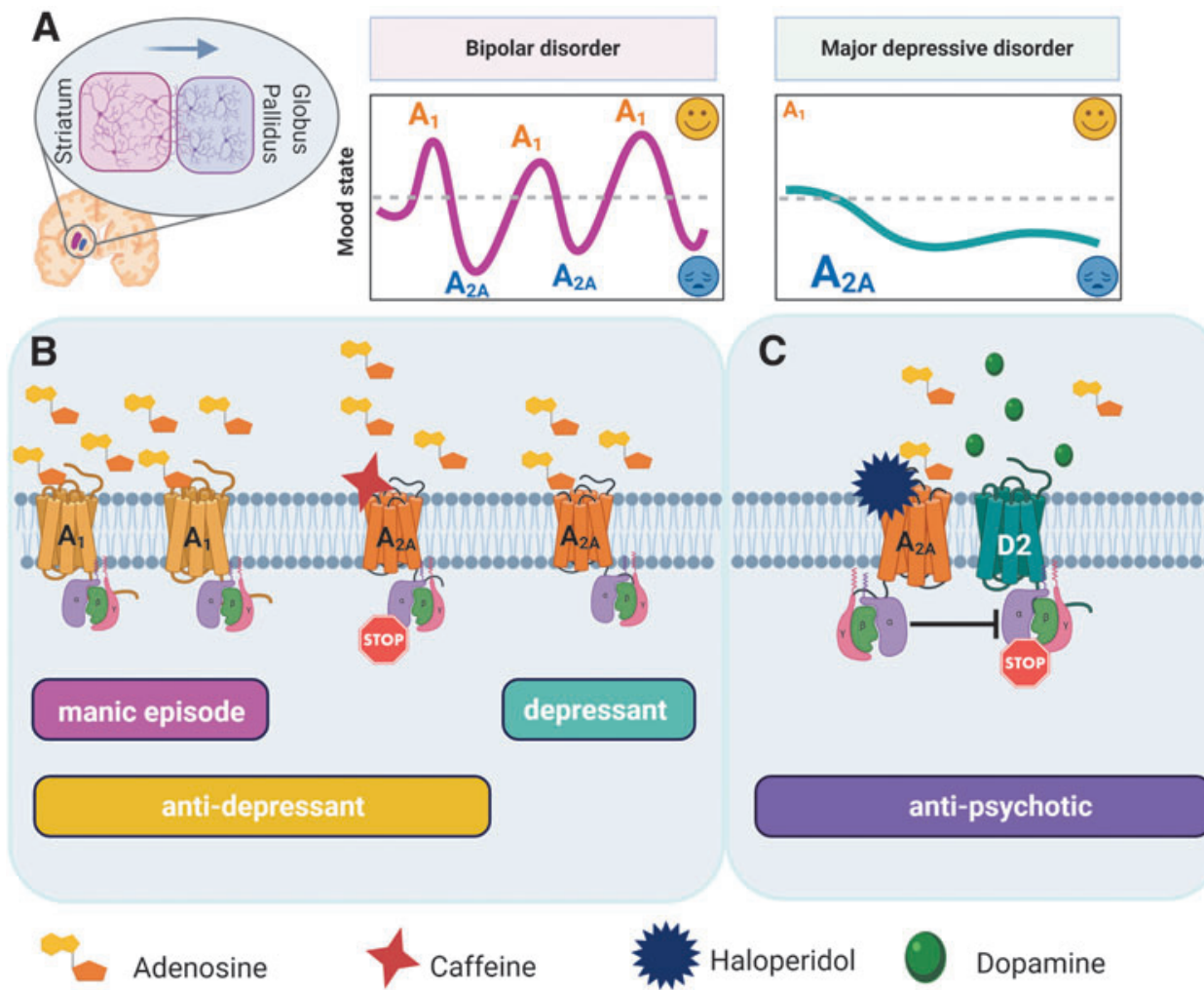

Adenosine

FIG. 1. Adenosinergic and dopaminergic control of mood symptoms. (A) Mood disorders, such as bipolar disorder and major depressive disorder, are neuropsychiatric conditions characterized by altered mood states. Modulation of adenosine $A_{1}$ and $A_{2 A}$ receptors expression and activity is associated to elevated mood and depressive-like symptoms, respectively, especially in striatopallidal neurons. (B) Adenosine receptors are G protein-coupled complexes activated by adenosine. While activation of the $\mathrm{A}_{1}$ receptor is associated with manic/hypomanic episodes and with the antidepressant effects of some drugs, activation of the $\mathrm{A}_{2 \mathrm{~A}}$ receptor is associated with depressive-like symptoms, which can be reversed to a normal state when receptor activity is antagonized, for example, by caffeine. (C) While psychosis can be a feature of mood disorders, mood alterations can occur as well in schizophrenia, characterizing the schizoaffective disorder. The antipsychotic effects of drugs widely used to treat schizophrenia and schizoaffective disorder, such as, haloperidol, result from the antagonistic association of $A_{2 A}$ and dopamine $D_{2}$ receptors to form $A_{2 A}-D_{2}$ receptor heteromers. The binding of haloperidol to the adenosine $\mathrm{A}_{2 \mathrm{~A}}$ receptor in the heteromer complex reduces the sensitivity of dopamine $\mathrm{D}_{2}$ receptor-binding sites to dopamine, which has an antipsychotic effect. 


\section{Authors' Contributions}

M.C.B.G. conceived and drafted the work, contributed to adenosine and mood control, dopamine and mood control, adenosine-dopamine interactions and implications in mood control and perspectives sections, as well as overall article organization; T.G. contributed to introduction and adenosine in mood control section and figure design; S.L.B.O. contributed to abstract and dopamine in mood control sections; H.U. conceived the study, contributed with the expertise to knowledge input for the insights here proposed and revised the article critically for important intellectual content. All authors have reviewed and approved the final version of the article before submission.

This original article has never been published before and has not been, nor will be, submitted elsewhere while under consideration for publication by Journal of Caffeine and Adenosine Research.

\section{Author Disclosure Statement}

No competing financial interests exist.

\section{Funding Information}

H.U. is grateful for grant support by the São Paulo Research State Foundation FAPESP (Project No. 2018/ 07366-4) and the National Council for Scientific and Technological Development CNPq (Project No. 306392/2017-8), Brazil. TG acknowledges a postdoctoral fellowship from FAPESP (Project No. 2015/ 13345-1), Brazil.

\section{References}

1. Kessler RC, Bromet EJ. The epidemiology of depression across cultures. Annu Rev Public Health. 2013; 34:119-138.

2. Friedrich MJ. Depression is the leading cause of disability around the world. JAMA. 2017;317:1517.

3. Coppen A. The biochemistry of affective disorders. Br J Psychiatry. 1967;113:1237-1264.

4. WHO. Mood disorders-ICD-11 for Mortality and Morbidity Statistics. Available from: https://icd.who .int/browse11/1-m/en\#/http://id.who.int/icd/entity/ 76398729. 2019, accessed June 23, 2020.

5. Rakofsky J, Rapaport M. Mood disorders. Contin Lifelong Learn Neurol. 2018;24:804-827.

6. Luca M, Prossimo G, Messina V, et al. Epidemiology and treatment of mood disorders in a day hospital setting from 1996 to 2007: An Italian study. Neuropsychiatr Dis Treat. 2013;9:169-176.

7. Menezes IC, von Werne Baes C, Lacchini R, et al. Genetic biomarkers for differential diagnosis of major depressive disorder and bipolar disorder: A systematic and critical review. Behav Brain Res. 2019;357-358: 29-38.

8. Ellenbroek B, Youn J. Affective Disorders. In: GeneEnvironment Interactions in Psychiatry: Nature, Nur- ture and Neuroscience. Cambridge, MA: Academic Press; 2016: pp. 173-231.

9. Malaspina D, Owen MJ, Heckers S, et al. Schizoaffective disorder in the DSM-5. Schizophr Res. 2013;150: 21-25.

10. Salvatore $\mathrm{P}$, Baldessarini RJ, Tohen $\mathrm{M}$, et al. McLeanHarvard International First-Episode Project: Two-year stability of DSM-IV diagnoses in 500 first-episode psychotic disorder patients. J Clin Psychiatry. 2009;70: 458-466.

11. Merikangas KR, Jin R, He J, et al. Prevalence and correlates of bipolar spectrum disorder in the World Mental Health Survey Initiative. Arch Gen Psychiatry. 2011;68:241-251.

12. Abrams DJ, Rojas DC, Arciniegas DB. Is schizoaffective disorder a distinct categorical diagnosis? A critical review of the literature. Neuropsychiatr Dis Treat. 2008;4:1089-1109.

13. Bhattacharya A, Derecki NC, Lovenberg TW, et al. Role of neuro-immunological factors in the pathophysiology of mood disorders. Psychopharmacology (Berl). 2016;233:1623-1636.

14. Falkai P, Malchow B, Schmitt A. Neurobiological background of affective disorders. In: Psychiatric Disorders-New Frontiers in Affective Disorders. D. Schoepf (Ed). London, UK: InTechOpen; 2013: pp. 3-20.

15. Fass DM, Schroeder FA, Perlis RH, et al. Epigenetic mechanisms in mood disorders: Targeting neuroplasticity. Neuroscience. 2014;264:112-130.

16. Pettinati HM, O'Brien CP, Dundon WD. Current status of co-occurring mood and substance use disorders: A new therapeutic target. Am J Psychiatry. 2013;170: 23-30.

17. Duncan WC. Circadian rhythms and the pharmacology of affective illness. Pharmacol Ther. 1996;71: 253-312.

18. Fredholm BB, Ijzerman AP, Jacobson KA, et al. International Union of Pharmacology. XXV. Nomenclature and classification of adenosine receptors. Pharmacol Rev. 2001;53:527-552.

19. Knight GE. Purinergic receptors. In: Encyclopedia of Neuroscience. L.R. Squire (Ed). Cambridge, MA: Academic Press; 2009: pp. 1245-1252.

20. Gandhi AV, Mosser EA, Oikonomou G, et al. Melato$\mathrm{nin}$ is required for the circadian regulation of sleep. Neuron. 2015;85:1193-1199.

21. Ferrante A, De Simone R, Ajmone-Cat MA, et al. Adenosine receptors and neuroinflammation. Receptors. 2018;34:217-237.

22. Fredholm BB, IJzerman AP, Jacobson KA, et al. International union of basic and clinical pharmacology. LXXXI. Nomenclature and classification of adenosine receptors-An update. Pharmacol Rev. 2011;63:1-34.

23. Cheffer A, Castillo ARG, Corrêa-Velloso J, et al. Purinergic system in psychiatric diseases. Mol Psychiatry. 2018;23:94-106.

24. Hines DJ, Schmitt LI, Hines RM, et al. Antidepressant effects of sleep deprivation require astrocyte-dependent adenosine mediated signaling. Transl Psychiatry. 2013; 3:e212.

25. Serchov T, Clement H-W, Schwarz MK, et al. Increased signaling via adenosine A1 receptors, sleep deprivation, 
imipramine, and ketamine inhibit depressive-like behavior via induction of homer1a. Neuron. 2015;87:549-562.

26. Serchov T, Atas HC, Normann C, et al. Genetically controlled upregulation of adenosine $\mathrm{A}(1)$ receptor expression enhances the survival of primary cortical neurons. Mol Neurobiol. 2012;46:535-544.

27. van Calker D, Biber K. The role of glial adenosine receptors in neural resilience and the neurobiology of mood disorders. Neurochem Res. 2005;30:1205-1217.

28. Cunha RA, Johansson B, Ploeg I, et al. Evidence for functionally important adenosine A2A receptors in the rat hippocampus. Brain Res. 1994;649:208-216.

29. Stockwell J, Jakova E, Cayabyab FS. Adenosine A1 and $\mathrm{A} 2 \mathrm{~A}$ receptors in the brain: Current research and their role in neurodegeneration. Molecules. 2017;22: 676.

30. Smith A. Effects of caffeine in chewing gum on mood and attention. Hum Psychopharmacol. 2009;24:239247.

31. El Yacoubi M, Ledent C, Parmentier M, et al. Adenosine A2A receptor antagonists are potential antidepressants: Evidence based on pharmacology and $\mathrm{A} 2 \mathrm{~A}$ receptor knockout mice. Br J Pharmacol. 2001;134:68-77.

32. El Yacoubi M, Costentin J, Vaugeois JM. Adenosine A2A receptors and depression. Neurology. 2003;61: S82-S87.

33. El Yacoubi M, Ledent $\mathrm{C}$, Parmentier M, et al. The anxiogenic-like effect of caffeine in two experimental procedures measuring anxiety in the mouse is not shared by selective $\mathrm{A}(2 \mathrm{~A})$ adenosine receptor antagonists. Psychopharmacol. 2000;148:153-163.

34. Hodgson RA, Bertorelli R, Varty GB, et al. Characterization of the potent and highly selective $\mathrm{A} 2 \mathrm{~A}$ receptor antagonists preladenant and SCH 412348 [7-[2-[4-2,4difluorophenyl]-1-piperazinyl]ethyl]-2-(2-furanyl)-7Hpyrazolo[4,3-e][1,2,4]triazolo[1,5-c]pyrimidin-5amine] in rodent models of movemen. J Pharmacol Exp Ther. 2009;330:294-303.

35. Yamada K, Kobayashi M, Mori A, et al. Antidepressant-like activity of the adenosine A(2A) receptor antagonist, istradefylline (KW-6002), in the forced swim test and the tail suspension test in rodents. Pharmacol Biochem Behav. 2013;114-115:23-30.

36. SanMiguel N, López-Cruz L, Müller CE, et al. Caffeine modulates voluntary alcohol intake in mice depending on the access conditions: Involvement of adenosine receptors and the role of individual differences. Pharmacol Biochem Behav. 2019;186:172789.

37. López-Cruz L, Salamone JD, Correa M. Caffeine and selective adenosine receptor antagonists as new therapeutic tools for the motivational symptoms of depression. Front Pharmacol. 2018;9:526.

38. Coelho JE, Alves P, Canas PM, et al. Overexpression of adenosine A2A receptors in rats: Effects on depression, locomotion, and anxiety. Front Psychiatry. 2014;5:1-8.

39. Crema LM, Pettenuzzo LF, Schlabitz M, et al. The effect of unpredictable chronic mild stress on depressivelike behavior and on hippocampal A1 and striatal A2A adenosine receptors. Physiol Behav. 2013;109:1-7.

40. Kaster MP, Machado NJ, Silva HB, et al. Caffeine acts through neuronal adenosine A2A receptors to prevent mood and memory dysfunction triggered by chronic stress. Proc Natl Acad Sci U S A. 2015;112:7833-7838.
41. Machado-Vieira R, Lara DR, Souza DO, et al. Purinergic dysfunction in mania: An integrative model. Med Hypotheses. 2002;58:297-304.

42. van Calker D, Biber K, Domschke K, et al. The role of adenosine receptors in mood and anxiety disorders. J Neurochem. 2019;151:11-27.

43. Ortiz R, Ulrich H, Zarate CA, et al. Purinergic system dysfunction in mood disorders: A key target for developing improved therapeutics. Prog Neuropsychopharmacol Biol Psychiatry. 2015;57:117-131.

44. Hirota T, Kishi T. Adenosine hypothesis in schizophrenia and bipolar disorder: A systematic review and metaanalysis of randomized controlled trial of adjuvant purinergic modulators. Schizophr Res. 2013;149:88-95.

45. Boison D, Singer P, Shen HY, et al. Adenosine hypothesis of schizophrenia-Opportunities for pharmacotherapy. Neuropharmacology. 2012;62:1527-1543.

46. Kurumaji A, Toru M. An increase in [3H] CGS21680 binding in the striatum of postmortem brains of chronic schizophrenics. Brain Res. 1998;808:320-323.

47. Lara DR, Dall'Igna OP, Ghisolfi ES, et al. Involvement of adenosine in the neurobiology of schizophrenia and its therapeutic implications. Prog Neuro Psychopharmacol Biol Psychiatry. 2006;30:617-629.

48. Brunstein MG, Belmonte-de-Abreu P, Souza DO, et al. Therapeutic benefit of adjunctive dipyridamole in schizophrenia is probably due to adenosine-glutamate interactions. J Clin Pharm Ther. 2001;26:155-156.

49. Salvadore G, Viale CI, Luckenbaugh DA, et al. Increased uric acid levels in drug-naive subjects with bipolar disorder during a first manic episode. Prog Neuropsychopharmacol Biol Psychiatry. 2010;34:819-821.

50. Bartoli F, Crocamo C, Gennaro GM, et al. Exploring the association between bipolar disorder and uric acid: A mediation analysis. J Psychosom Res. 2016; 84:56-59.

51. Bartoli F, Carrà G, Clerici M. Update on bipolar disorder biomarker candidates: What about uric acid/adenosine hypothesis? Expert Rev Mol Diagn. 2017;17:105-106.

52. Akhondzadeh S, Milajerdi MR, Amini $\mathrm{H}$, et al. Allopurinol as an adjunct to lithium and haloperidol for treatment of patients with acute mania: A doubleblind, randomized, placebo-controlled trial. Bipolar Disord. 2006;8:485-489.

53. Machado-Vieira R, Soares JC, Lara DR, et al. A double-blind, randomized, placebo-controlled 4-week study on the efficacy and safety of the purinergic agents allopurinol and dipyridamole adjunctive to lithium in acute bipolar mania. J Clin Psychiatry. 2008;69:12371245.

54. Jahangard L, Soroush S, Haghighi M, et al. In a doubleblind, randomized and placebo-controlled trial, adjuvant allopurinol improved symptoms of mania in inpatients suffering from bipolar disorder. Eur Neuropsychopharmacol. 2014;24:1210-1221.

55. Gubert C, Jacintho Moritz CE, Vasconcelos-Moreno MP, et al. Peripheral adenosine levels in euthymic patients with bipolar disorder. Psychiatry Res. 2016;246: 421-426.

56. Lewis KS, Gordon-Smith K, Forty L, et al. Sleep loss as a trigger of mood episodes in bipolar disorder: Individual differences based on diagnostic subtype and gender. Br J Psychiatry. 2017;211:169-174. 
57. Baldessarini RJ, Tondo L, Vazquez GH. Pharmacological treatment of adult bipolar disorder. Mol Psychiatry. 2019;24:198-217.

58. Martini C, Tuscano D, Trincavelli ML, et al. Upregulation of A2A adenosine receptors in platelets from patients affected by bipolar disorders under treatment with typical antipsychotics. J Psychiatr Res. 2006;40: 81-88.

59. Bartoli F, Clerici M, Carrà G. Purinergic system and suicidal behavior: Exploring the link between adenosine A2A receptors and depressive/impulsive features. Mol Psychiatry. 2020;25:512-513.

60. Gonçalves MCB, Corrêa-Velloso J, Naaldijk Y, et al. Purinergic modulation of pathways associated to suicidal behavior. Mol Psychiatry. 2020;25:514-516.

61. Brown JH, Makman MH. Stimulation by dopamine of adenylate cyclase in retinal homogenates and of adenosine-3':5' -cyclic monophosphate formation in intact retina. Proc Natl Acad Sci U S A. 1972;69:539543.

62. Kebabian JW, Petzold GL, Greengard P. Dopaminesensitive adenylate cyclase in caudate nucleus of rat brain, and its similarity to the "dopamine receptor." Proc Natl Acad Sci U S A. 1972;69:2145-2149.

63. Mishra A, Singh S, Shukla S. Physiological and functional basis of dopamine receptors and their role in neurogenesis: Possible implication for Parkinson's disease. J Exp Neurosci. 12:1179069518779829.

64. Jaber M, Robinson SW, Missale C, et al. Dopamine receptors and brain function. Neuropharmacology. 1996; 35:1503-1519.

65. Gurevich EV, Gainetdinov RR, Gurevich VV. $\mathrm{G}$ protein-coupled receptor kinases as regulators of dopamine receptor functions. Pharmacol Res. 2016;111: $1-16$.

66. Beaulieu JM, Espinoza S, Gainetdinov RR. Dopamine receptors-IUPHAR review 13. Br J Pharmacol. 2015;172:1-23.

67. Cooper H, Mishriky R, Reyad AA. Efficacy and safety of cariprazine in acute management of psychiatric disorders: A meta-analysis of randomized controlled trials. Psychiatr Danub. 2020;32:36.

68. Gründer G. Cariprazine, an orally active D2/D3 receptor antagonist, for the potential treatment of schizophrenia, bipolar mania and depression. Curr Opin Investig Drugs. 2010;11:823-832.

69. Duric V, Banasr M, Franklin T, et al. Cariprazine exhibits anxiolytic and dopamine D3 receptor-dependent antidepressant effects in the chronic stress model. Int J Neuropsychopharmacol. 2017;20:788-796.

70. Zhang B, Guo F, Ma Y, et al. Activation of D1R/PKA/mTOR signaling cascade in medial prefrontal cortex underlying the antidepressant effects of 1-SPD. Sci Rep. 2017;7:1-10.

71. Freund N, Thompson BS, Sonntag K, et al. When the party is over: Depressive-like states in rats following termination of cortical D1 receptor overexpression. Psychopharmacology (Berl). 2016;233:1191-1201.

72. Young JW, Goey AKL, Minassian A, et al. GBR 12909 administration as a mouse model of bipolar disorder mania: Mimicking quantitative assessment of manic behavior. Psychopharmacology (Berl). 2010;208:443454 .
73. Freyberg Z, Sonders MS, Aguilar JI, et al. Mechanisms of amphetamine action illuminated through optical monitoring of dopamine synaptic vesicles in Drosophila brain. Nat Commun. 2016;7:10652.

74. Perona MTG, Waters S, Hall FS, et al. Animal models of depression in dopamine, serotonin, and norepinephrine transporter knockout mice: Prominent effects of dopamine transporter deletions. Behav Pharmacol. 2008;19:566-574.

75. Pantazopoulos H, Stone D, Walsh J, et al. Differences in the cellular distribution of D1 receptor mRNA in the hippocampus of bipolars and schizophrenics. Synapse. 2004;54:147-155.

76. Kaalund SS, Newburn EN, Ye T, et al. Contrasting changes in DRD1 and DRD2 splice variant expression in schizophrenia and affective disorders, and associations with SNPs in postmortem brain. Mol Psychiatry. 2014; 19:1258-1266.

77. Zhan L, Kerr JR, Lafuente M-J, et al. Altered expression and coregulation of dopamine signalling genes in schizophrenia and bipolar disorder. Neuropathol Appl Neurobiol. 2011;37:206-219.

78. Vogel M, Pfeifer S, Schaub RT, et al. Decreased levels of dopamine $\mathrm{D}_{3}$ receptor mRNA in schizophrenic and bipolar patients. Neuropsychobiology. 2004;50:305310.

79. Xiang L, Szebeni K, Szebeni A, et al. Dopamine receptor gene expression in human amygdaloid nuclei: Elevated D4 receptor mRNA in major depression. Brain Res. 2008;1207:214-224.

80. Hirvonen J, Karlsson H, Kajander J, et al. Striatal dopamine D2 receptors in medication-naive patients with major depressive disorder as assessed with [11C]raclopride PET. Psychopharmacology (Berl). 2008;197:581-590.

81. Lehto SM, Kuikka J, Tolmunen T, et al. Temporal cortex dopamine $\mathrm{D}_{2 / 3}$ receptor binding in major depression. Psychiatry Clin Neurosci. 2008;62:345-348.

82. Klimek V, Schenck JE, Han H, et al. Dopaminergic abnormalities in amygdaloid nuclei in major depression: A postmortem study. Biol Psychiatry. 2002;52:740-748.

83. Peciña M, Sikora M, Avery ET, et al. Striatal dopamine D2/3 receptor-mediated neurotransmission in major depression: Implications for anhedonia, anxiety and treatment response. Eur Neuropsychopharmacol. 2017;27: 977-986.

84. Schneier FR, Slifstein M, Whitton AE, et al. Dopamine release in antidepressant-naive major depressive disorder: A multimodal [11C]-(+)-PHNO positron emission tomography and functional magnetic resonance imaging study. Biol Psychiatry. 2018;84:563-573.

85. Tiger M, Svensson J, Liberg B, et al. $\left[{ }^{11} \mathrm{C}\right]$ raclopride positron emission tomography study of dopamine- $\mathrm{D}_{2 / 3}$ receptor binding in patients with severe major depressive episodes before and after electroconvulsive therapy and compared to control subjects. Psychiatry Clin Neurosci. 2020;74:263-269.

86. Montgomery AJ, Stokes P, Kitamura Y, et al. Extrastriatal D2 and striatal D2 receptors in depressive illness: Pilot PET studies using [11C]FLB 457 and [11C]raclopride. J Affect Disord. 2007;101:113-122.

87. Hamilton JP, Sacchet MD, Hjørnevik T, et al. Striatal dopamine deficits predict reductions in striatal 
functional connectivity in major depression: A concurrent $11 \mathrm{C}$-raclopride positron emission tomography and functional magnetic resonance imaging investigation. Transl Psychiatry. 2018;8:1-10.

88. Cannon DM, Klaver JM, Peck SA, et al. Dopamine type-1 receptor binding in major depressive disorder assessed using positron emission tomography and [11C]NNC-112. Neuropsychopharmacology. 2009;34: $1277-1287$.

89. Yao J, Pan Y, Ding M, et al. Meta-analysis shows dopamine receptor D1 gene polymorphism is associated with bipolar disorder but not with schizophrenia. Psychiatry Res. 2013;210:1324-1325.

90. Dmitrzak-Weglarz M, Rybakowski JK, Slopien A, et al. Dopamine receptor D1 gene $-48 \mathrm{~A} / \mathrm{G}$ polymorphism is associated with bipolar illness but not with schizophrenia in a polish population. Neuropsychobiology. 2006;53:46-50.

91. He M, Yan H, Duan Z-X, et al. Genetic distribution and association analysis of DRD2 gene polymorphisms with major depressive disorder in the Chinese Han population-PubMed. Int J Clin Exp Pathol. 2013;6: 1142-1149.

92. Serretti A, Macciardi F, Cusin C, et al. Linkage of mood disorders with D2, D3 and TH genes: A multicenter study. J Affect Disord. 2000;58:51-61.

93. Lee S-Y, Chen S-L, Chang Y-H, et al. The ALDH2 and DRD2/ANKK1 genes interacted in bipolar II but not bipolar I disorder. Pharmacogenet Genomics. 2010;20: 500-506.

94. Wang YS, Lee SY, Chen SL, et al. Role of DRD2 and ALDH2 genes in bipolar II disorder with and without comorbid anxiety disorder. Eur Psychiatry. 2014;29: 142-148.

95. Massat I, Souery D, Del-Favero J, et al. Positive association of dopamine D2 receptor polymorphism with bipolar affective disorder in a European multicenter association study of affective disorders. Am J Med Genet. 2002;114:177-185.

96. Squassina A, Manchia M, Costa M, et al. Age at onset in bipolar disorder: Investigation of the role of TaqIA polymorphism of DRD2 gene in a Sardinian sample. Eur Psychiatry. 2011;26:141-143.

97. Savitz J, Hodgkinson CA, Martin-Soelch C, et al. DRD2/ANKK1 Taq1A polymorphism (rs1800497) has opposing effects on D2/3 receptor binding in healthy controls and patients with major depressive disorder. Int J Neuropsychopharmacol. 2013;16:20952101.

98. Wang Y, Liu X, Yu Y, et al. The role of single nucleotide polymorphism of D2 dopamine receptor gene on major depressive disorder and response to antidepressant treatment. Psychiatry Res. 2012;200:1047-1050.

99. Lee SY, Chen SL, Chen SH, et al. The COMT and DRD3 genes interacted in bipolar i but not bipolar II disorder. World J Biol Psychiatry. 2011;12:385-391.

100. Lin CI, Lee SY, Chang YH, et al. Temperaments $\times$ genes in bipolar I and bipolar II disorder patients. Psychiatry Res. 2010;177:364-366.

101. Zhao L, Lin Y, Lao G, et al. Association study of dopamine receptor genes polymorphism with cognitive functions in bipolar i disorder patients. J Affect Disord. 2015;170:85-90.
102. Gonçalves VF, Tiwari AK, de Luca V, et al. DRD4 VNTR polymorphism and age at onset of severe mental illnesses. Neurosci Lett. 2012;519:9-13.

103. Fuxe K, Ungerstedt U. Action of caffeine and theophyllamine on supersensitive dopamine receptors: Considerable enhancement of receptor response to treatment with DOPA and dopamine receptor agonists. Med Biol. 1974;52:48-54.

104. Ferre S, Von Euler G, Johansson B, et al. Stimulation of high-affinity adenosine $\mathrm{A} 2$ receptors decreases the affinity of dopamine D2 receptors in rat striatal membranes. Proc Natl Acad Sci U S A. 1991;88:7238-7241.

105. Ferré S, Ciruela F, Woods AS, et al. Functional relevance of neurotransmitter receptor heteromers in the central nervous system. Trends Neurosci. 2007;30: 440-446.

106. Ferré S, Baler R, Bouvier M, et al. Building a new conceptual framework for receptor heteromers. Nat Chem Biol. 2009;5:131-134.

107. Fuxe K, Marcellino D, Borroto-Escuela DO, et al. Adenosine-dopamine interactions in the pathophysiology and treatment of cns disorders. CNS Neurosci Ther. 2010;16:e18.

108. Shen H-Y, Chen J-F. Adenosine A2A receptors in psychopharmacology: Modulators of behavior, mood and cognition. Curr Neuropharmacol. 2009;7:195-206.

109. Mishina M, Ishiwata K, Kimura Y, et al. Evaluation of distribution of adenosine $\mathrm{A} 2 \mathrm{~A}$ receptors in normal human brain measured with [11C]TMSX PET. Synapse. 2007;61:778-784.

110. Schiffmann SN, Fisone G, Moresco R, et al. Adenosine A2A receptors and basal ganglia physiology. Prog Neurobiol. 2007;83:277-292.

111. Li Y, He Y, Chen M, et al. Optogenetic activation of adenosine $\mathrm{A} 2 \mathrm{~A}$ receptor signaling in the dorsomedial striatopallidal neurons suppresses goal-directed behavior. Neuropsychopharmacology. 2016;41:10031013.

112. Ferre S, Quiroz C, Woods A, et al. An update on adenosine A2A-dopamine D2 receptor interactions: Implications for the function of $G$ protein-coupled receptors. Curr Pharm Des. 2008;14:1468-1474.

113. Marchand WR, Yurgelun-Todd D. Striatal structure and function in mood disorders: A comprehensive review. Bipolar Disord. 2010;12:764-785.

114. Ferré S, Bonaventura J, Zhu W, et al. Essential control of the function of the striatopallidal neuron by precoupled complexes of adenosine A2A-dopamine D2 receptor heterotetramers and adenylyl cyclase. Front Pharmacol. 2018;9:243.

115. Fuxe K, Borroto-Escuela DO, Tarakanov AO, et al. Dopamine D2 heteroreceptor complexes and their receptor-receptor interactions in ventral striatum: Novel targets for antipsychotic drugs. Prog Brain Res. 2014;211:113-139.

116. Sahlholm K, Gómez-Soler M, Valle-León M, et al. Antipsychotic-like efficacy of dopamine D2 receptorbiased ligands is dependent on adenosine A2A receptor expression. Mol Neurobiol. 2018;55:4952-4958.

117. Borroto-Escuela DO, Pintsuk J, Schäfer T, et al. Multiple D2 heteroreceptor complexes: New targets for treatment of schizophrenia. Ther Adv Psychopharmacol. 2016;6:77-94. 
118. Fuxe K, Ferré S, Genedani S, et al. Adenosine receptordopamine receptor interactions in the basal ganglia and their relevance for brain function. Physiol Behav. 2007; 92:210-217.

119. Lodge DJ, Grace AA. The hippocampus modulates dopamine neuron responsivity by regulating the intensity of phasic neuron activation. Neuropsychopharmacology. 2006;31:1356-1361.

120. Floresco SB, West AR, Ash B, et al. Afferent modulation of dopamine neuron firing differentially regulates tonic and phasic dopamine transmission. Nat Neurosci. 2003;6:968-973.

121. Grace AA. Dopamine system dysregulation by the hippocampus: Implications for the pathophysiology and treatment of schizophrenia. Neuropharmacology. 2012;62:1342-1348.

122. Belujon P, Grace AA. Dopamine system dysregulation in major depressive disorders | International Journal of Neuropsychopharmacology | Oxford Academic. Int J Neuropsychopharmacol. 2017;20:1036-1046.

123. Kendell SF, Krystal JH, Sanacora G. GABA and glutamate systems as therapeutic targets in depression and mood disorders. Expert Opin Ther Targets. 2005;9: 153-168.

124. Jun C, Choi Y, Lim SM, et al. Disturbance of the glutamatergic system in mood disorders. Exp Neurobiol. 2014;23:28-35.

125. Rao JS, Kellom M, Reese EA, et al. Dysregulated glutamate and dopamine transporters in postmortem frontal cortex from bipolar and schizophrenic patients. J Affect Disord. 2012;136:63-71.

126. Chiapponi C, Piras F, Piras F, et al. GABA system in schizophrenia and mood disorders: A mini review on third-generation imaging studies. Front Psychiatry. 2016;7:61

127. Brambilla P, Perez J, Barale F, et al. GABAergic dysfunction in mood disorders. Mol Psychiatry. 2003;8: 721-737.
128. Vaz SH, Lérias SR, Parreira S, et al. Adenosine A2A receptor activation is determinant for BDNF actions upon GABA and glutamate release from rat hippocampal synaptosomes. Purinergic Signal. 2015;11:607-612.

129. Niciu MJ, Iadarola ND, Banerjee D, et al. The antidepressant efficacy of subanesthetic-dose ketamine does not correlate with baseline subcortical volumes in a replication sample with major depressive disorder. J Psychopharmacol. 2017;31:1570-1577.

130. Sokoloff P, Le Foll B. The dopamine D3 receptor, a quarter century later. Eur J Neurosci. 2017;45:2-19.

131. Torvinen M, Marcellino D, Canals M, et al. Adenosine $\mathrm{A} 2 \mathrm{~A}$ receptor and dopamine $\mathrm{D} 3$ receptor interactions: Evidence of functional A2A/D3 heteromeric complexes. Mol Pharmacol. 2005;67:400-407.

132. Perreault ML, Hasbi A, O'dowd BF, et al. Heteromeric dopamine receptor signaling complexes: Emerging neurobiology and disease relevance. Neuropsychopharmacology. 2014;39:156-168.

133. Fuxe K, Canals M, Torvinen M, et al. Intramembrane receptor-receptor interactions: A novel principle in molecular medicine. J Neural Transm. 2007;114:49-75.

134. Fuxe K, Marcellino D, Rivera A, et al. Receptorreceptor interactions within receptor mosaics. Impact on neuropsychopharmacology. Brain Res Rev. 2008; $58: 415-452$.
Address correspondence to: Henning Ulrich, PhD

Departamento de Bioquímica Instituto de Química

Universidade de São Paulo

Av. Prof. Lineu Prestes, 748

São Paulo, SP 05508-000

Brazil

E-mail: henning@iq.usp.br 